\title{
Influence of energy balance on the antimicrobial peptides S100A8 and S100A9 in the endometrium of the post-partum dairy cow
}

\author{
Theerawat Swangchan-Uthai ${ }^{1,2}$, Qiusheng Chen $^{3}$, Sally E Kirton ${ }^{1}$, Mark A Fenwick ${ }^{1}$, \\ Zhangrui Cheng ${ }^{1}$, Joe Patton ${ }^{4}$, Ali A Fouladi-Nashta ${ }^{1}$ and D Claire Wathes ${ }^{1}$ \\ ${ }^{1}$ Reproduction Group, Royal Veterinary College, Hawkshead Lane, North Mymms, Hatfield, Herts AL9 7TA, UK, \\ ${ }^{2}$ Department of Obstetrics, Gynaecology and Reproduction, Faculty of Veterinary Science, Chulalongkorn University, \\ Bangkok 10330, Thailand, ${ }^{3}$ College of Veterinary Medicine, Nanjing Agricultural University, Nanjing, People's \\ Republic of China and ${ }^{4}$ Teagasc Moorepark, Dairy Production Research Centre, Fermoy, Co. Cork, Ireland
}

Correspondence should be addressed to D C Wathes; Email: dcwathes@rvc.ac.uk

\begin{abstract}
Uterine inflammation occurs after calving in association with extensive endometrial remodelling and bacterial contamination. If the inflammation persists, it leads to reduced fertility. Chronic endometritis is highly prevalent in high-yielding cows that experience negative energy balance (NEB) in early lactation. This study investigated the effect of NEB on the antimicrobial peptides S100A8 and S100A9 in involuting uteri collected 2 weeks post partum. Holstein-Friesian cows (six per treatment) were randomly allocated to two interventions designed to produce mild or severe NEB (MNEB and SNEB) status. Endometrial samples were examined histologically, and the presence of neutrophils, macrophages, lymphocytes and natural killer cells was confirmed using haematoxylin and eosin and immunostaining. SNEB cows had greater signs of uterine inflammation. Samples of previously gravid uterine horn were used to localise S100A8 and S100A9 by immunohistochemistry. Both $\mathrm{S100}$ proteins were present in bovine endometrium with strong staining in epithelial and stromal cells and in infiltrated leucocytes. Immunostaining was significantly higher in SNEB cows along with increased numbers of segmented neutrophils. These results suggest that the metabolic changes of a post-partum cow suffering from NEB delay uterine involution and promote a chronic state of inflammation. We show that upregulation of S100A8 and S100A9 is clearly a key component of the early endometrial response to uterine infection. Further studies are warranted to link the extent of this response after calving to the likelihood of cows developing endometritis and to their subsequent fertility.
\end{abstract}

Reproduction (2013) 145 527-539

\section{Introduction}

The post-partum period is critical for subsequent fertility in dairy cows, as the resumption of ovarian cyclicity and uterine recovery are both essential before conception can occur again (Sheldon 2004). Uterine bacterial contamination is almost universal after calving (Foldi et al. 2006). In most cows, this is eliminated during the process of involution, but cows that fail to eliminate potentially pathogenic microorganisms can develop metritis or endometritis (Sheldon 2004, Chapwanya et al. 2009). These diseases are highly prevalent in high-yielding cows (LeBlanc et al. 2002, Gilbert et al. 2005) and are associated with an inflammatory response. Endometritis was described by Bondurant (1999) as a superficial inflammation of the endometrium extending no deeper than the stromal layer, with some disruption of the surface epithelium, infiltration with inflammatory cells (neutrophils, macrophages, eosinophils, mast cells, lymphocytes and plasma cells), vascular congestion and stromal oedema. An increase in segmented neutrophils (or polymorphonuclear leukocytes, PMNs) in the endometrium was associated with poor reproductive performance, whereas the presence of lymphocytic foci in endometrium was associated with good fertility (Bonnett et al. 1993). Endometritis causes economic losses through increases in calving interval, a higher culling rate for infertility, and reduced milk yield (Dobson \& Smith 1998, Gilbert et al. 2005).

The endometrium is the first line of defence against invading microorganisms. Rapid defence mechanisms are provided by innate immunity, which recognises pathogens mainly by the family of toll-like receptors (TLRs; Werling \& Jungi 2003). Among the TLR family members, TLR4, found in bovine endometrial epithelial 
and stromal cells, is capable of recognising lipopolysaccharide (LPS) from Gram-negative bacteria including Escherichia coli (Herath et al. 2006). LPS binds to MD2 (an LPS-binding protein) and interacts with CD14 (the main LPS receptor) and then with TLR4, thus activating a signal transduction pathway in cells. This leads to the production of a number of cytokines and chemokines (Chapwanya et al. 2009, Fischer et al. 2010, Galvao et al. 2011), antimicrobial peptides (AMPs), acute phase proteins (APPs) (Davies et al. 2008, Chapwanya et al. 2012) and prostaglandins (Herath et al. 2009a). We have previously shown that several AMPs involved in innate immunity, including both defensins and calcium-binding proteins S100, are expressed in bovine endometrium (Wathes et al. 2009).

S100A8 and S100A9 are calcium-binding proteins that belong to the $\mathrm{S} 100$ protein family (Kligman \& Hilt 1988). They have previously been reported to have a variety of actions in innate immunity (Vandal et al. 2003), as an antimicrobial (Sohnle et al. 2000), in wound healing (Thorey et al. 2001) and they also act as a survival factor for early-stage embryos (Passey et al. 1999). S100A8 and S100A9 are mainly found as cytosolic protein in neutrophils and monocytes (Ahmad et al. 2003) but they have also been detected in other cell types and tissues such as leukocytes, fibroblasts, tumour cell lines and bone marrow (Dale et al. 1985, Rahimi et al. 2005) including both squamous epithelia and nonsquamous cell types (Matsumoto et al. 1997). They were also present in the human reproductive tract (myometrium and cervix) around parturition (Havelock et al. 2005). We recently demonstrated that LPS caused a rapid upregulation of S100A8, S100A9 and S100A12 mRNAs and S100A8 protein in cultured bovine endometrium (Swangchan-Uthai et al. 2012).

Genetic selection of dairy cows for high milk yields has been associated with a reduction in fertility (Veerkamp et al. 2001). Modern dairy cows are often unable to meet their energy requirements for body maintenance and milk production and then enter a stage of negative energy balance (NEB). This is associated with excessive lipid metabolism and loss of body condition score (BCS), resulting in metabolic disorders via alterations in blood metabolites and subsequently reduced fertility (Roche et al. 2000, Butler 2003, Wathes et al. 2007). During the nadir of NEB, the limitations on nutrient availability also impair immune function such as neutrophil activity (Hammon et al. 2006). This in turn appears to increase the susceptibility to infections such as endometritis and mastitis (Wathes 2012).

By developing an energy balance model to provide two groups of cows with induced mild or severe NEB (MNEB and SNEB) status in early lactation, we previously demonstrated that NEB can affect many systems in the body that contribute to successful pregnancy. This included effects on the liver, spleen, ovary and oviduct as well as the uterine environment (reviewed by Wathes et al. (2008) and Wathes (2012)). As the genes encoding S100A8 and S100A9 were highly upregulated in the endometrium of SNEB cows (Wathes et al. 2009), we speculated that these proteins may act as an indicator of the severity of endometrial inflammation after calving. This idea was supported by a recent review of the literature concerning the role of the S100 family in obstetrics and gynaecology, which reported associations between the amounts of S100A8 and S100A9 in endometrial and cervical cancer respectively (Kostakis et al. 2010). However, the localisation of these proteins in the endometrium and the factors influencing their production in vivo has not, to our knowledge, been investigated previously. In this study, we have examined the presence of S100A 8 and S100A9 in bovine endometrium and their relationship with metabolic status and endometrial inflammation in post-partum dairy cows experiencing different degrees of NEB. Our hypothesis is that the metabolic changes associated with SNEB delays uterine clearance mechanisms and promotes a chronic state of inflammation that can detrimentally affect fertility.

\section{Results}

Energy balance and hormone and metabolite measurements collected from a cohort of 12 multiparous Holstein-Friesian dairy cows managed to achieve a state of MNEB or SNEB after calving has been reported in detail previously (Fenwick et al. 2008). In summary, the net energy values on the day of killing for tissue sample collection ( $13.6 \pm 0.8$ and $14.3 \pm 0.6$ days respectively) were about threefold lower in the SNEB than in the MNEB cows $(-2.7 \pm 1.41$ vs $-6.1 \pm 1.03$ unite fourragère lait (UFL)/day). The SNEB cows had clear evidence of fatty liver, associated with lipid infiltration. Circulating concentrations of non-esterified fatty acids (NEFA) and beta-hydroxybutyrate (BHB) were elevated in SNEB and IGF1 and glucose levels were significantly decreased. All SNEB cows were thus in subclinical ketosis ( $\geq 1.2 \mathrm{mmol} / \mathrm{l})$ with plasma BHB concentrations ranging from 3.0 to $4.5 \mathrm{mmol} / \mathrm{l}$.

\section{Immune cell infiltration into the endometrium}

Histological analysis based on haematoxylin and eosin $(\mathrm{H} \& \mathrm{E})$ staining was performed separately for the previously gravid and non-gravid uterine horns (with diameters of $56 \pm 7$ vs $31 \pm 3 \mathrm{~mm}$ respectively, values are mean \pm S.E.M.) and in each horn separately for the caruncular and intercaruncular regions. Segmented cells representing neutrophils were found in the luminal and glandular epithelium and the stroma in all sections examined (Fig. 1A). Mononuclear cells representing lymphocytes were found as lymphocytic foci in the stroma and in the basement of the luminal epithelium (Fig. 1B). The number of segmented neutrophils in both 

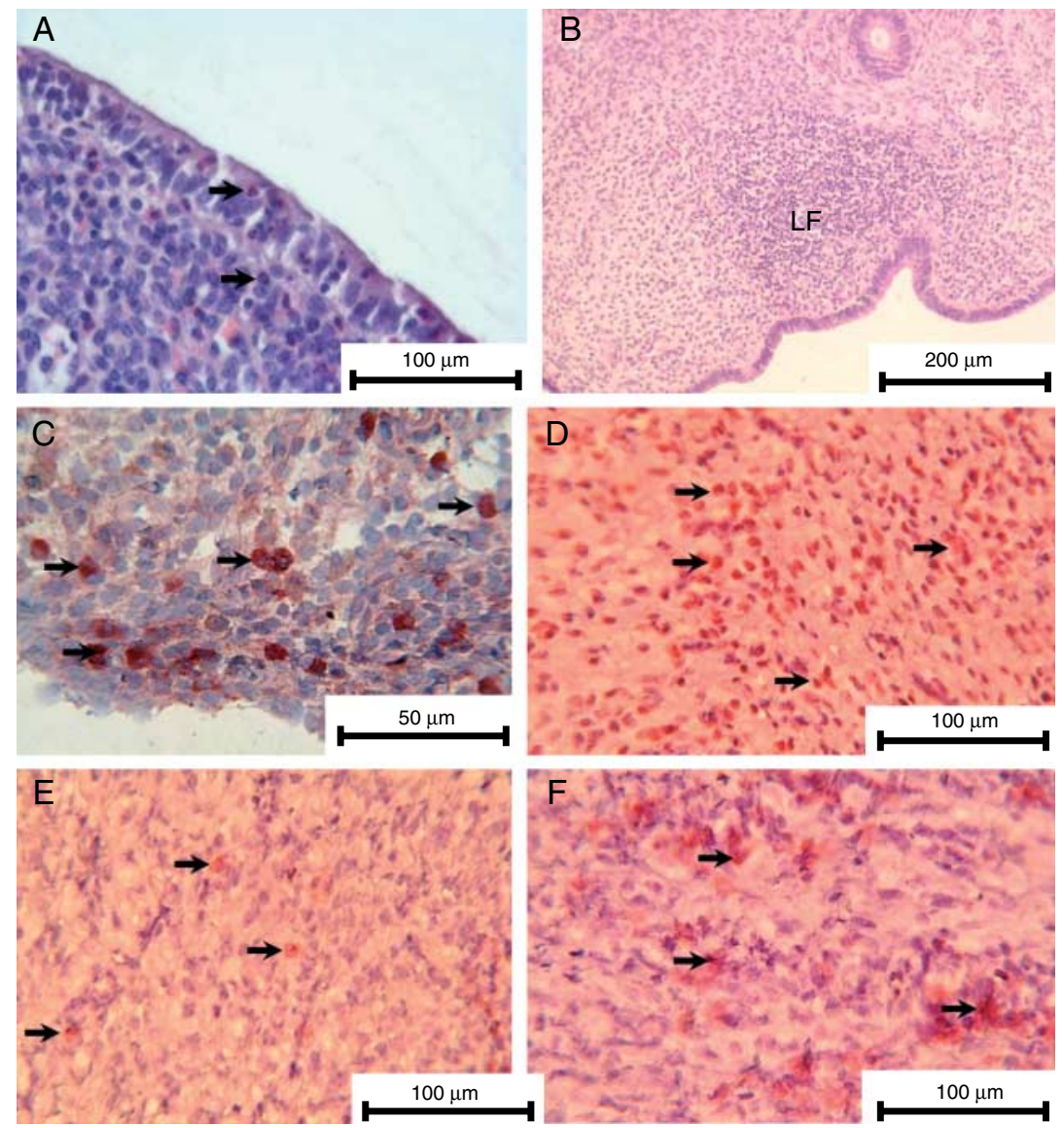

Figure 1 Representative photomicrographs of post-partum bovine endometrium stained with $\mathrm{H} \& \mathrm{E}$ ( $A$ and $B$ ) and using immunohistochemistry for CD172A (a macrophage and granulocyte marker, C); CD14 (a macrophage marker, D); CD2 (a T-cell and NK cell marker, E) and CD8 (a cytotoxic T-cell marker, F). In A, the arrows indicate segmented neutrophils in both luminal epithelium and stroma. $B$ shows a lymphocytic focus (LF) in the stroma. The arrows in $\mathrm{C}, \mathrm{D}, \mathrm{E}$, and $\mathrm{F}$ ) indicate positive immunostaining of immune cells. luminal epithelium and stroma was significantly higher in SNEB cows than in MNEB cows $(77.8 \pm 20.4$ vs $22.4 \pm 6.6$ cells per graticule, $P<0.05 ; 9.2 \pm 1.3$ vs $3.8 \pm 0.83$ cells per $10 \mu \mathrm{m}^{2}, P<0.01$ respectively). More stromal lymphocytic foci per section were also detected in SNEB cows $(6.2 \pm 1.0$ vs $2.0 \pm 0.5, P<0.001)$. Mean macrophage numbers in endometrial tissues were not different between the SNEB and the MNEB groups. SNEB cows also had more capillaries (7.2 \pm 0.6 vs $5.1 \pm 0.4$ and $7.4 \pm 0.4$ vs $5.8 \pm 0.5$ per $20 \mu \mathrm{m}^{2}$ in gravid horn and non-gravid horns respectively, both $P<0.05$ ).

Immunohistochemistry was used to confirm the identity of the immune cell types present in the endometrium. Positive immunostaining was detected for tyrosine protein phosphatase non-receptor type substrate 1 (CD172A, representing macrophages and granulocytes, Fig. 1C), CD14 cell surface antigen (a macrophage marker; Fig. 1D), CD2 molecule (T-cell and natural killer (NK) cell marker; Fig. 1E) and T-cell surface glycoprotein CD8 (cytotoxic T-cell marker; Fig. 1F).

\section{S100A8 and S100A9 in the endometrium}

Positive immunostaining for both S100A8 and S100A9 was noted in the endometrial epithelial and stromal layers of both intercaruncular and caruncular regions from all 12 cows (Fig. 2A, B, C, D, E, and F). Liver was used as a positive control tissue (Fig. $2 \mathrm{G}$ and $\mathrm{H}$ ), whereas neither S100A8 nor S100A9 was detectable in the ovarian tissues examined (Fig. 2J and K). The isotype IgG-negative controls are also shown in Fig. 2C, $\mathrm{F}, \mathrm{I}$, and $\mathrm{L}$.

Localisation of S100A8 and S100A9 within different endometrial regions of interest (ROI) is illustrated in Fig. 3. The levels of immunostaining varied between cows, but in general, there was strong or moderate positive staining in luminal epithelium and infiltrated leukocytes in both luminal epithelium and stroma, whereas staining in the glandular epithelium was weak or absent. Mixed model analysis was next used to compare staining patterns of the protein S100A8 and S100A9 assessed from $\mathrm{H}$-score measurements in the endometrium according to i) NEB status (MNEB and SNEB) and ii) ROls. Overall levels of S100A8 and S100A9 in the SNEB group were higher when compared with the MNEB group (Fig. 4A and B). S100A8 and S100A9 immunostaining was relatively higher in the luminal epithelium and stroma of both caruncular and intercaruncular endometrium compared with the intercaruncular glandular epithelium. In addition, the 

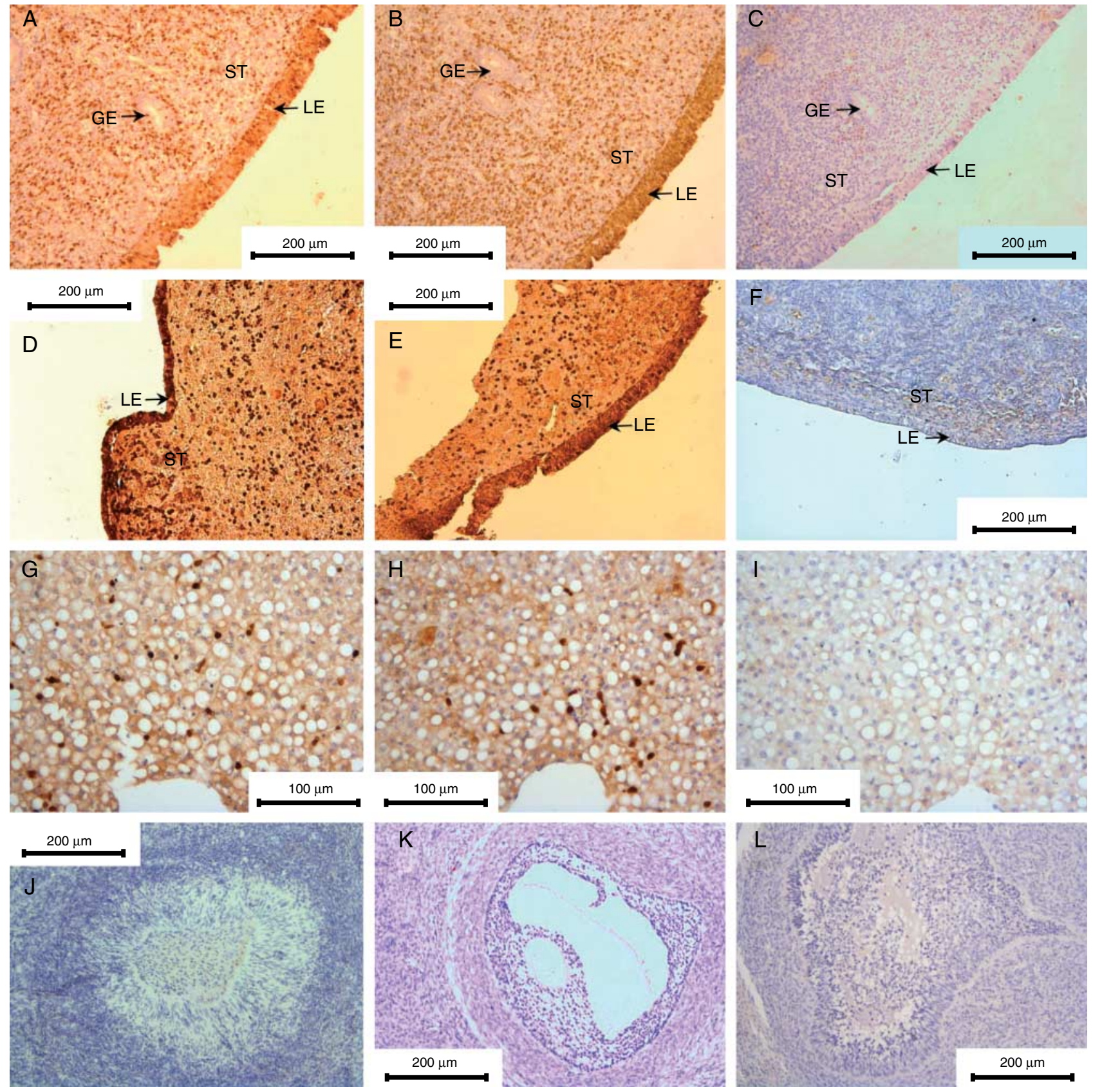

Figure 2 Representative photomicrographs of post-partum bovine endometrium showing immunostaining for S100A8 (A, D, G, and J), S100A9 (B, E, $\mathrm{H}$, and $\mathrm{K})$ and isotype IgG-negative control $(\mathrm{C}, \mathrm{F}, \mathrm{I}$, and $\mathrm{L})$ in the intercaruncular $(\mathrm{A}, \mathrm{B}$, and $\mathrm{C})$ and caruncular regions $(\mathrm{D}, \mathrm{E}$, and F). Liver $(\mathrm{G}, \mathrm{H}$, and $\mathrm{I})$ was used as a positive control tissue and ovary $(\mathrm{J}, \mathrm{K}$, and $\mathrm{L}$ ) as a negative control tissue. The sections were counterstained with haematoxylin. LE, luminal epithelium; GE, glandular epithelium; ST, stroma.

luminal epithelium of both caruncular and intercaruncular endometrium expressed S100A9 protein more highly than the caruncular stroma (Fig. 4C and D). Effects of NEB group were mainly significant in the luminal epithelium, although the $\mathrm{H}$-scores were consistently numerically higher in the SNEB cows for all ROIs. These differences in immunostaining patterns between the MNEB and SNEB groups are further illustrated in Fig. 5, in which one representative cow from each EB group is compared.

\section{Correlation analysis}

Pearson correlations, corrected for false discovery rate, were performed to suggest relationships between the $\mathrm{H}$-score values for endometrial S100A8 and S100A9 with other factors, using data across all cows $(n=12)$. S100A8 protein levels in each ROI were positively correlated with those of S100A9 in the same region (Table 1), showing that both proteins were upregulated together. 

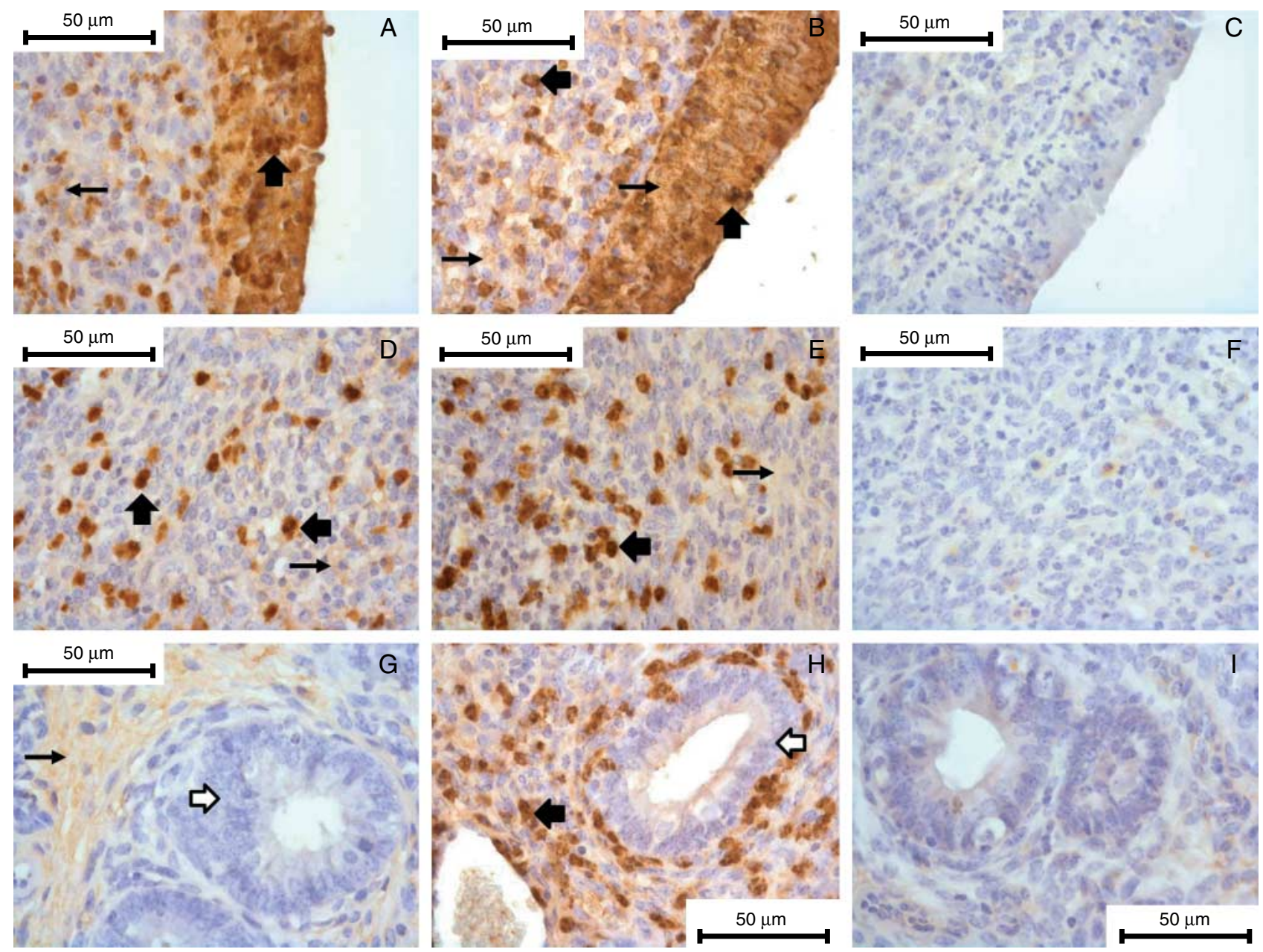

Figure 3 Representative photomicrographs of post-partum bovine endometrium in the intercaruncular region showing immunostaining for $\mathrm{S} 100 \mathrm{~A} 8$ $(A, D$, and $G)$, S100A9 (B, E, and H) and isotype-negative control $(C, F$, and I) showing (, , B, and C) luminal epithelium, (D, E, and F) stroma and $(\mathrm{G}, \mathrm{H}$, and $\mathrm{I})$ glandular epithelium. Strong positive staining in luminal epithelium and infiltrated leukocytes in both luminal epithelium and stroma is indicated by large closed arrows. Moderate staining (small arrows) in stroma and negative to weak staining (open arrows) in glandular epithelium can also be noted.

The S100A8 mRNA concentrations measured by both qPCR and from the microarray were correlated with the S100A8 immunostaining levels (Table 2). The mRNA levels of S100A8, S100A9 and S100A12 from the microarray data were consistently positively correlated with the immunostaining levels of S100A8 and S100A9 in the luminal epithelium of both intercaruncular and caruncular tissue $(P<0.05$, Table 2$)$. There were also some significant relationships with protein levels in the caruncular stroma and glandular epithelium. Significant correlations were also found between S100A8 and S100A9 protein levels with the concentration of S100A 12 mRNA. In contrast, there were no significant correlations between the immunostaining results and mRNA levels of another S100 family member present on the microarray, S100A2 (Table 2).

The levels of immunostaining were also related to the number of immune cells counted in the endometrium from the H\&E-stained sections (Table 2). The number of segmented neutrophils infiltrated in the epithelium was correlated with S100A8 and S100A9 immunostaining $\mathrm{H}$-score in the glandular epithelium, caruncular epithelium and caruncular stroma, while the number of segmented neutrophils infiltrated in the stroma correlated with protein levels in the intercaruncular and caruncular luminal epithelium. No significant relationships were detected with either the number of monocytes in the epithelium or stroma or the number of lymphocytic foci in the stroma (data not shown).

\section{Discussion}

This study was conducted to investigate immunostaining patterns of the AMPs S100A8 and S100A9 during the post-partum period of dairy cattle. The specimens were collected $\sim 2$ weeks after calving. At this stage, the caruncle is expected to be undergoing degeneration and sloughing after placental separation and re-epithelisation 

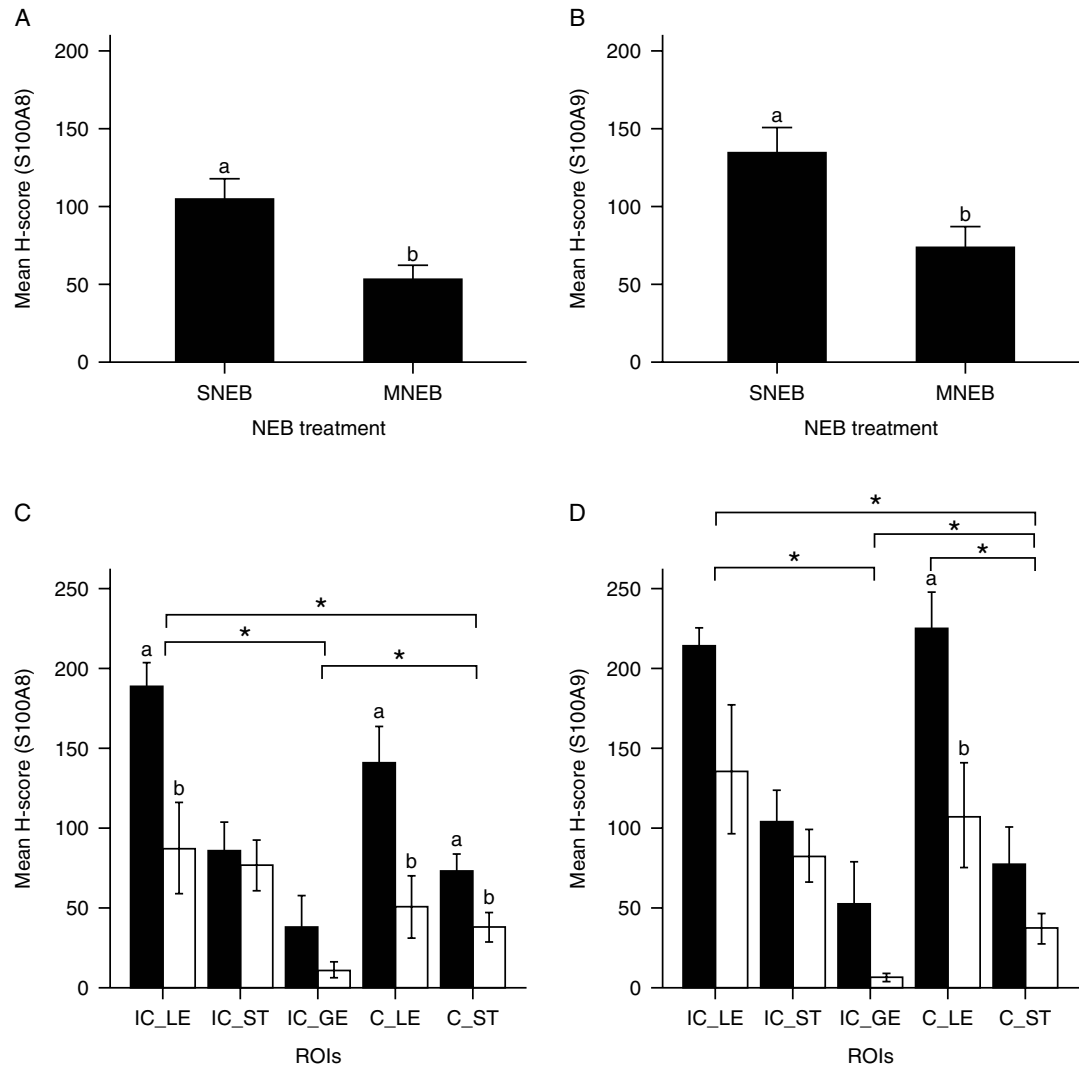

Figure 4 The overall expression (mean H-score \pm
S.E.M.) of (A) S100A8 and (B) S100A9 in bovine
endometrium according to treatment group (severe
or mild negative energy balance, SNEB and MNEB
respectively), $n=6$ cows per group: a $>$ b, $P<0.05$.
H-score \pm S.E.M. of (C) S100A8 and (D) S100A9 in
different regions of interest (ROIs) compared
between SNEB and MNEB cows (solid and open
bars respectively): IC_LE, intercaruncular luminal
epithelium; IC_ST, intercaruncular stroma; IC_GE,
intercaruncular glandular epithelium; C_LE,
caruncular luminal epithelium; C_ST, caruncular
stroma. Different superscript letters indicate signi-
ficant differences between treatment groups (a $>b$ ),
whereas asterisks $(*)$ indicate differences between
ROIs $(P<0.05$ ).

of the endometrium has not yet been completed (Gier \& Marion 1968). Both epithelial and stromal cells are commonly contaminated with microbes that produce endotoxins, before self-clearance, which should occur within 6 weeks post partum (Griffin et al. 1974). Highyielding cows can take up to 20 weeks post partum to regain a positive energy balance status (Taylor et al. 2003). Thus, the endometrial samples used in this study were collected from animals suffering to various degrees of NEB. They were taken from cows that had not yet resumed oestrous cycles after calving to avoid a potential effect of differential stage of the cycle on the specimens.

Drackley (1999) proposed that inflammation was a missing link in dairy cows between systemic and local uterine pathology as a consequence of metabolic disorders in the transition period (between 3 weeks before and 3 weeks after calving). Many lines of evidence have since supported this relationship. For example, experimentally induced fatty liver in cows resulted in the activation of circulatory TNF $\alpha$ activities and increased levels of the APPs haptoglobin and serum amyloid A (SAA; Ohtsuka et al. 2001, Ametaj et al. 2009). Using gene microarrays, 103 of the 197 recognised differentially expressed genes in endometrium of SNEB compared with MNEB cows were associated with immune or inflammatory responses (Wathes et al. 2009). Recently, Chapwanya et al.
(2012) found an increase in endometrial inflammation and leukocyte infiltration together with increased mRNA levels of pro-inflammatory AMP and APP genes during the early post-partum period in cows. Two studies that examined endometrial biopsies obtained during the post-partum period revealed that mRNA levels of $T L R 4$; the pro-inflammatory cytokines $T N F, I L 6, I L 1 A$ and $I L 1 B$; the receptor $I L 1 R 2$; and the chemokines CXCL5 and IL8 were higher in infertile cows with persistent endometritis than in cows with no clinical signs or subclinical endometritis (Herath et al. 2009b, Fischer et al. 2010). Our histological study of uterine specimens in the energy balance model reported here also provides strong evidence for an ongoing inflammatory reaction with more segmented neutrophils in the endometrium and oedema at 2 weeks post partum when cows were in SNEB.

In cyclic and early pregnant cows, $\mathrm{T}$ and $\mathrm{B}$ lymphocytes were present in the sub-epithelial stroma but they were rarely found within the luminal epithelium or the uterine lumen. Macrophages were, however, commonly located within both the uterine sub-epithelial stroma and the luminal epithelium (Leung et al. 2000). Similarly, Cobb \& Watson (1995) observed macrophages, $\mathrm{T}$ lymphocytes including $\mathrm{CD} 5+, \mathrm{CD} 4+$ and CD8 + cells and lymphocytic foci in the endometrium of heifers, but in their study, no B-cells were identified. 

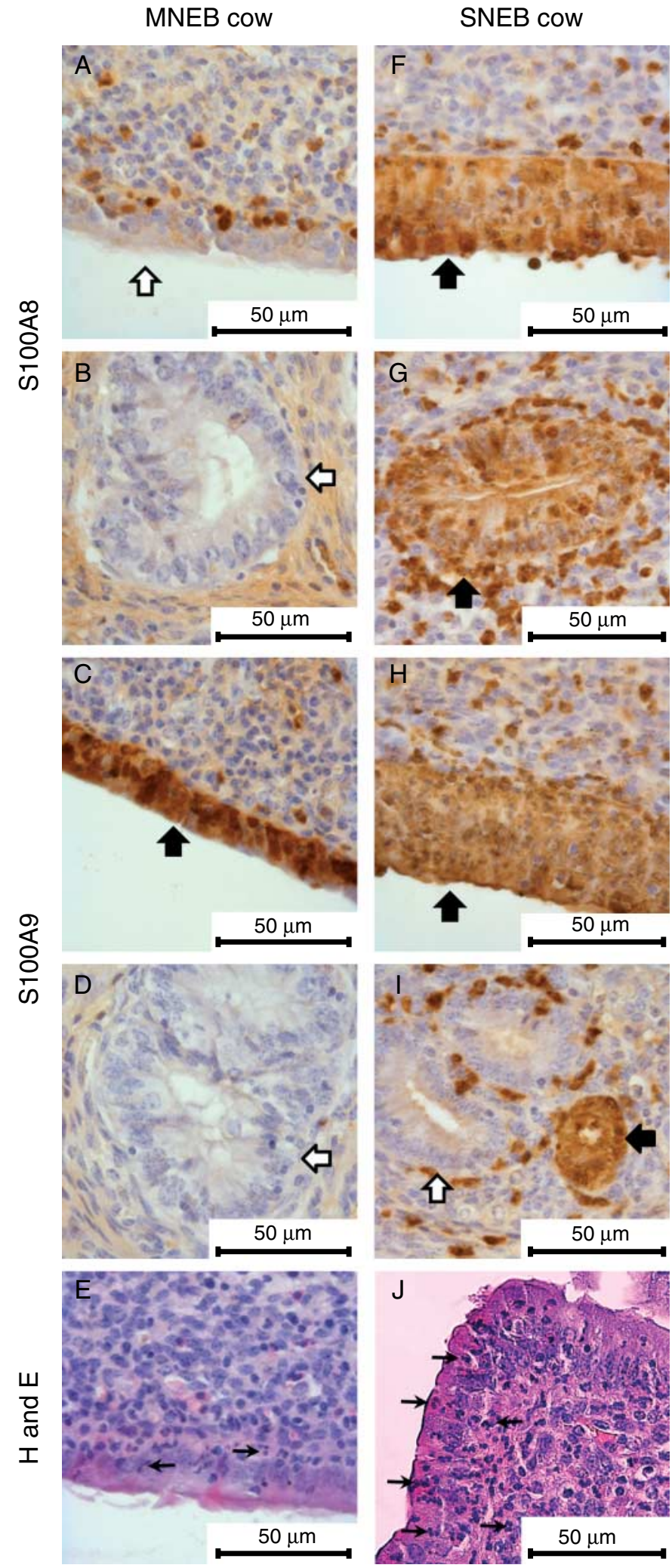

Figure 5 Photomicrographs of post-partum bovine endometrium to compare a representative cow in MNEB and one in SNEB. Immunostaining for S100A8 (A, B, F, and G) and S100A9 (C, D, H, and I) in luminal epithelium (A, C, F, and H) and glandular epithelium (B, D, G, and H). Strong positive staining in luminal epithelium and infiltrated leukocytes in both luminal epithelium and stroma is indicated by large closed arrows. Negative to weak staining (open arrows) in luminal and glandular epithelium can also be noted in the MNEB cow. (E and J) H\&E-stained sections showing segmented neutrophils in the epithelium and stoma (small arrows). 
Table 1 Summary of Pearson correlation coefficients $(r)$ between the immunostaining value $(\mathrm{H}$-score) of S100A8 and S100A9 in different endometrial regions from post-partum dairy cows ${ }^{\mathrm{a}}$.

\begin{tabular}{llllll}
\hline & \multicolumn{5}{c}{ S100A8 } \\
\cline { 2 - 6 } H-score & IC_LE & IC_GE & IC_ST & C_LE & C_ST \\
\hline S100A9 & & & & & \\
IC_LE & $\mathbf{0 . 9 1 2}^{+}$ & 0.283 & 0.521 & $\mathbf{0 . 7 3 9}^{*}$ & $\mathbf{0 . 6 3 5}^{*}$ \\
IC_GE & $\mathbf{0 . 6 2 5}^{*}$ & $\mathbf{0 . 6 7 4}^{*}$ & 0.147 & $\mathbf{0 . 7 3 7}^{*}$ & $\mathbf{0 . 6 5 7}^{*}$ \\
IC_ST & $\mathbf{0 . 6 6 2}^{*}$ & 0.306 & $\mathbf{0 . 8 9 0}^{+}$ & $\mathbf{0 . 6 5 2}^{*}$ & $\mathbf{0 . 6 8 5}^{*}$ \\
C_LE & $\mathbf{0 . 9 5 5}^{+}$ & $\mathbf{0 . 6 0 7}^{*}$ & 0.540 & $\mathbf{0 . 9 5 1}^{+}$ & $\mathbf{0 . 8 9 6}^{+}$ \\
C_ST & 0.560 & $\mathbf{0 . 7 5 4}^{*}$ & 0.427 & $\mathbf{0 . 6 8 6}^{*}$ & $\mathbf{0 . 7 2 6}^{*}$ \\
\hline
\end{tabular}

IC, intercaruncular; C, caruncular; LE, luminal epithelium; GE, glandular epithelium; ST, stroma. Correlations highlighted in bold are significant at $* P<0.05$ or ${ }^{\dagger} P<0.01$ (two-tailed).

a Values are from unadjusted data and are combined across treatment groups (mild and severe NEB, six cows per group).

PMNs were evident in bovine endometrium undergoing inflammatory processes (Santos et al. 2009) but there were fewer in healthy cows $(<2 \%$ of all samples) (Fischer et al. 2010). Lymphocytic foci are commonly present in the bovine uterus after parturition (Bonnett et al. 1991) and in animals with endometritis (Hartigan et al. 1972). Using immunostaining, we confirmed here the presence of granulocytes, lymphocytes, macrophages, T-cell and NK cells in the bovine post-partum endometrium, with clear evidence of cells in the luminal epithelium where they would be best placed to defend against invading microbes.

The endometrium is protected against microorganisms and their toxins not only by physical barriers but also by the production of several effectors such as AMPs and complement via TLRs and other pattern recognition receptors (Sheldon \& Bromfield 2011). The work presented here provides the first evidence that the AMPs S100A8 and S100A9 are localised in both epithelial and stromal cells of the endometrium in addition to segmented neutrophils and that protein levels were significantly higher when cows were experiencing SNEB. Indeed, the majority of immunopositive-stained cells in the post-partum endometrium were surface luminal epithelial and stromal cells. Thus, it appears that the endometrium itself functions as the firstline bacterial detector. The significant positive correlations between the $\mathrm{H}$-scores of S100A8 and S100A9 using immunohistochemistry and their mRNA levels as measured by microarray or qPCR confirm the reliability of the measurements made. This was further supported by the significant correlations with S100A12 but not with S100A2 mRNA. We have previously reported upregulation of S100A12 in cultured endometrium challenged with LPS (Swangchan-Uthai et al. 2012), indicating a role in immune function, whereas $5100 A 2$ is involved in cell cycle progression and cell migration and is thought to be a biomarker for several cancers (Naz et al. 2012). The number of infiltrated segmented neutrophils in endometrium relates directly to the severity of the inflammation (Chapwanya et al. 2009). The correlation of immunostaining levels with neutrophil number, particularly in the luminal epithelium, thus firmly links upregulation of S100A8 and S100A9 to an ongoing inflammatory process in response to bacterial contamination after calving.

Defensins and cathelicidins are endogenous mediators primarily involved in cell homoeostasis, but they can also activate an immune response as extracellular danger signals when released as a result of cell damage or induced secretion (Yang \& Oppenheim 2009). They have thus been termed danger-associated molecular pattern molecules. S100 proteins also appear to function in this way. During endometrial culture, intracellular S100A8 protein levels were high, with little evidence of secretion into the medium (Swangchan-Uthai et al. 2012). In post-partum cows, however, the ongoing inflammation is associated with

Table 2 Summary of Pearson correlation coefficients $(r)$ between the protein levels (H-score) of S100A8 and S100A9 in different endometrial regions from post-partum dairy cows with mRNA values measured by qPCR and microarray and with the number of segmented neutrophils in histological samples assessed using H\&E staining ${ }^{\mathrm{a}}$.

\begin{tabular}{|c|c|c|c|c|c|c|c|}
\hline \multirow[b]{2}{*}{$\underline{\mathbf{H} \text {-score (protein) }}$} & \multirow{2}{*}{$\begin{array}{c}\text { qPCR } \\
S 100 A 8\end{array}$} & \multicolumn{4}{|c|}{ Microarray results (mRNA) } & \multicolumn{2}{|c|}{ No. of segmented neutrophils } \\
\hline & & S100A8 & S100A9 & S100A12 & S100A2 & Epithelium & Stroma \\
\hline \multicolumn{8}{|l|}{ S100A8 } \\
\hline IC_LE & $0.756^{*}$ & $0.796 *$ & $0.700^{*}$ & $0.792 *$ & 0.493 & 0.566 & $0.747^{+}$ \\
\hline IC_GE & 0.508 & 0.596 & 0.733* & 0.561 & 0.276 & $0.748^{+}$ & 0.518 \\
\hline IC_ST & 0.034 & 0.152 & 0.042 & 0.129 & -0.259 & 0.180 & 0.278 \\
\hline C_LE & $0.729 *$ & $0.0788^{*}$ & $0.749 *$ & $0.765^{*}$ & 0.434 & $0.651^{*}$ & $0.680^{*}$ \\
\hline C_ST & 0.685* & 0.733* & 0.701* & $0.711^{*}$ & 0.349 & $0.684 *$ & 0.622 \\
\hline \multicolumn{8}{|l|}{ S100A9 } \\
\hline IC_LE & $0.747^{*}$ & 0.773* & 0.639 & $0.771^{+}$ & 0.479 & 0.429 & $0.697 *$ \\
\hline IC_GE & 0.576 & 0.592 & $0.747^{\dagger}$ & 0.537 & 0.268 & 0.604* & 0.615 \\
\hline IC_ST & 0.230 & 0.249 & 0.221 & 0.225 & -0.225 & 0.263 & 0.501 \\
\hline C_LE & 0.768* & 0.834* & $0.766^{*}$ & $0.815^{\dagger}$ & 0.499 & 0.704* & $0.734^{+}$ \\
\hline C_ST & 0.506 & 0.657 & $0.710^{*}$ & 0.614 & 0.328 & $\mathrm{0.893}^{+}$ & 0.577 \\
\hline
\end{tabular}

IC, intercaruncular; C, caruncular; LE, luminal epithelium; GE, glandular epithelium; ST, stroma. Correlations highlighted in bold are significant at ${ }^{*} P<0.05$ or $^{\dagger} P<0.01$ (two-tailed).

a Values are from unadjusted data and are combined across treatment groups (mild $n=6$ and severe NEB, $n=5$ ). 
damage to the surface epithelium (Bondurant 1999), which may allow leakage of the S100 family proteins into both uterine secretions and the circulation. S100A8 and S100A9 can form a heterocomplex calprotectin, which is able to inhibit bacterial growth by chelating $\mathrm{Zn}^{2+}$ and preventing invasion of organisms through the cell membrane (Steinbakk et al. 1990, Nisapakultorn et al. 2001). Recently, it has been suggested that the S100A9 subunit was essential to the ability of calprotectin to resist bacterial infection (Champaiboon et al. 2009).

TLR4 is the key receptor of the mammalian endometrium, which recognises the LPS component of invading Gram-negative bacteria (Khan et al. 2009, Sheldon \& Roberts 2010, Chotimanukul \& Sirivaidyapong 2011). We previously showed that LPS treatment in vitro upregulated S100A8 and S100A9 mRNAs, peaking after $12 \mathrm{~h}$, indicating that this represents a key component of the innate immune response (Swangchan-Uthai et al. 2012). There is also strong evidence for an autocrinepositive feedback loop whereby endogenous S100A8 and S100A9 and calprotectin are capable of activating both TLR4 (Vogl et al. 2007) and AGER, the receptor for advanced glycation end products (Turovskaya et al. 2008), resulting in an amplification of endotoxin-induced upregulation of cytokines, chemokines and other inflammatory mediators (Ehrchen et al. 2009).

We previously described measurements of the APP SAA in the same cohort of experimental cows used in this study (Wathes et al. 2009). SAA concentrations peaked at day 1-3 post partum and then fell by the time of specimen collection around day 14, in agreement with previous studies (Sheldon 2004, Ametaj et al. 2009). The average plasma SAA levels in all experimental cows on the day of tissue collection was 92.3 $\pm 80.0 \mathrm{mg} / \mathrm{ml}(n=12$, mean \pm s.D.; range from lower than detection limit to $178 \mathrm{mg} / \mathrm{ml}$ ). There was no correlation between plasma SAA levels at this time and the parameters recorded in this study, including metabolites, hormones, number of segmented neutrophils and the protein or mRNA levels S100A8 and S100A9 in the endometrial specimens (data not shown). Previous studies have shown that hepatic expression of the $S A A 1$ gene was elevated during the periparturient period in association with increased NEFA levels (Loor et al. 2005) and our results from the energy balance model used in this study support the evidence for an acute phase response in early post-partum cows with fatty liver. In contrast, endometrial $\mathrm{H}$-scores for S100A8 and S100A9 showed strong positive correlation with the number of segmented neutrophils in endometrial samples. This may indicate that these S100 proteins reflect the severity of endometrial inflammation in post-partum cows more closely than other known biomarkers such as the APPs, which are more strongly influenced by hepatic pathology.

In summary, poor energy balance in early post-partum dairy cows has a deleterious effect on the degree of endometrial inflammation. S100A8 and S100A9 were detected locally in the luminal and glandular epithelium and stroma of bovine endometrium as well as in immune cells. It was suggested that these proteins are involved in the activation of cytokines, chemokines and inflammatory mediators through LPS binding to TLR4/MD2 complexes. Upregulation of S100A8 and S100A9 is clearly a key component of the endometrial response to infection in post-partum cows. Further studies are warranted to determine possible links in dairy cattle between the extent of this response after calving, the likelihood of developing clinical and subclinical endometritis and subsequent fertility.

\section{Materials and Methods}

All chemicals and reagents were purchased from SigmaAldrich Company Ltd. or VWR International Ltd. (Poole, Dorset, UK) unless otherwise specified.

\section{Animals and experimental design}

All experimental procedures were conducted in accordance with the European Community Directive, 86-609-EC. The experiment was performed at Teagasc, Moorepark Production Research Centre, Ireland, and described previously (Fenwick et al. 2008, Wathes et al. 2011). In brief, 12 animals from an initial pool of 24 multiparous Holstein-Friesian cows with an average previous lactation yield of $6477 \pm 354 \mathrm{~kg}$ were used in this study. At 2 weeks before expected calving, the cows were randomly allocated to two interventions designed to produce MNEB or SNEB status. From day 2 or 3 post-calving, MNEB cows were fed ad libitum grass silage with $8 \mathrm{~kg}$ of a $21 \%$ crude protein dairy concentrate and milked $\times 1$ per day, while SNEB cows were restricted in dietary intake, i.e. fed with $25 \mathrm{~kg}$ grass silage and $4 \mathrm{~kg}$ concentrate and milked three times per day. Energy balance status was monitored daily using the French NEL system and presented as UFL per day where 1 UFL is the net energy for lactation equivalent of $1 \mathrm{~kg}$ of standard air-dry barley. Measurements of BCS and energy balance status were used to select six cows from each group.

Transrectal ovarian ultrasonography (Aloka SSD-500 7.5 MHz transducer; Aloka Ltd, Tokyo, Japan) was used to monitor ovarian activity daily from day 7 post partum to detect the first follicular wave. All cows were killed on days 6-7 after the appearance of the first follicular wave. This design was chosen to collect tissue at a fixed time in relation to the start of ovarian cycles to allow subsequent analysis at the same stage of follicle development. The average post-partum interval of MNEB and SNEB groups at killing was $13.6 \pm 0.8$ and $14.3 \pm 0.6$ days respectively. Tissue and blood samples were collected at this time.

\section{Blood sampling, metabolite and hormone determinations}

Blood samples were obtained from all animals by jugular venipuncture on the day of killing for measurement of 
hormones and metabolites. Samples were collected into lithium-heparinized vials and placed on ice before centrifugation at $2000 \mathrm{~g}$ for $10 \mathrm{~min}$. Plasma was decanted and stored at $-20{ }^{\circ} \mathrm{C}$ for subsequent analysis. Plasma concentrations of metabolites and hormones were measured and reported previously (Fenwick et al. 2008). Plasma IGF1 concentrations were determined using human OCTEIA IGF-I kits (IDS, Tyne and Wear, UK), whereas plasma glucose, NEFA, BHB, triglyceride and urea concentrations were measured using commercially available kits (Randox Laboratories Ltd, Crumlin, Co. Antrim, UK) and an ABX Mira autoanalyzer (ABX Mira, Cedex, France). SAA concentrations were measured in serum using the Tridelta Phase range SAA solid-phase ELISA kit according to the manufacturer's guidelines (Tridelta Co., Kildare, Ireland). For hormones, insulin concentrations were determined using the solid-phase RIA Coat-A-Count Insulin kit (Siemens Medical Solutions Diagnostics, Los Angeles, CA, USA) and plasma oestradiol concentrations were measured using the Oestradiol MAIA assay kit (BioStat Diagnostic Systems, Cheshire, UK).

\section{Tissue collection}

Endometrial specimens were obtained from 12 cows $(n=6$ in each group) enrolled to one of the two treatments designed to produce MNEB and SNEB status. Samples of uterine tissue (caruncular and intercaruncular) from the body, mid-region and tip from both horns were fixed in $4 \%$ paraformaldehyde and embedded in paraffin. For assessment of the mRNA levels, samples of intercaruncular endometrial tissue weighing $\sim 1 \mathrm{~g}$ were dissected from the midportion of the previously gravid horn $1 \mathrm{~cm}$ anterior to the bifurcation of the uterus. These were rinsed in RNase-free phosphate buffer, snap-frozen in liquid nitrogen and stored at $80{ }^{\circ} \mathrm{C}$.

\section{Histology}

Paraffin-embedded samples were sectioned at $10 \mu \mathrm{m}$ and mounted on glass slides. Endometrial sections of each animal were stained with H\&E. The sections were deparaffinised and rehydrated in a graded series of ethanol. The slides were incubated in $10 \%(\mathrm{v} / \mathrm{v})$ Gill's Haematoxylin No. 3 in $\mathrm{dH}_{2} \mathrm{O}$ (Park Scientific Ltd., Northampton, UK) for $4 \mathrm{~min}$ and washed with running tap water for $5 \mathrm{~min}$. They were then placed in $\mathrm{dH}_{2} \mathrm{O}$ before incubating in $1 \%(\mathrm{w} / \mathrm{v})$ eosin (Sigma) in $\mathrm{dH}_{2} \mathrm{O}$ for $1 \mathrm{~min}$ and washed in $\mathrm{dH}_{2} \mathrm{O}(2 \times 2 \mathrm{~min})$. The stained sections were dehydrated and mounted with VectaMount permanent Mounting Medium (Vector Laboratories, Peterborough, UK) before applying coverslips.

The H\&E-stained specimens were used to assess the degree of uterine inflammation as described by Bonnett et al. (1991). Inflammatory cells were subdivided into segmented (neutrophils) or mononuclear cells (macrophages and lymphocytes). The number of segmented and mononuclear cells was the mean of three sections per horn (gravid and non-gravid), taken in each case from the uterine tip and a caruncular region and an intercaruncular region from the mid-region under a Nikon 187907 light microscope ( $\times 400$ magnification). Those in epithelium were expressed as number per graticule length and those in stroma as the average number of cells per $10 \mu \mathrm{m}^{2}$. The number of lymphocytic foci was counted in stroma under a light microscope ( $\times 100$ magnification) and was expressed as the number per section. Capillary density in the stroma (stratum compactum) was measured as the number of cross sections in $20 \mu \mathrm{m}^{2}$ averaged over four sites per section.

\section{Immunohistochemistry}

Samples from previously gravid uterine horns were subjected to optimised immunoperoxidase staining for proteins S100A8 and S100A9 and leukocyte markers. In addition, liver and ovarian tissues were used as positive and negative control tissues respectively for S100A8 and S100A9. The paraffin-embedded samples were cut into $6 \mu \mathrm{m}$-thick sections, applied onto $\mathrm{HCl}$ treated poly-L-lysine-coated slides and left to dry in an incubator at $37^{\circ} \mathrm{C}$ for $24 \mathrm{~h}$ before use.

Immunohistochemical localisation of proteins S100A8 and S100A9 was performed using an immunoperoxidase staining procedure, Vectastain Elite ABC Kit (Vector Laboratories), in accordance with guidelines supplied by the manufacturer. Tissue sections were deparaffinised in Histo-Clear tissue clearing agent (Fisher Scientific, Loughborough, UK) and rehydrated in a graded series of ethanol. The sections were immersed in $0.3 \%$ hydrogen peroxide in methanol for $60 \mathrm{~min}$ to inactivate endogenous peroxidase, washed in $\mathrm{PBS} \mathrm{pH} 7.5$ twice for $5 \mathrm{~min}$ each and then subjected to microwave pretreatment for $7 \mathrm{~min}$ twice at $700 \mathrm{~W}$ in $0.01 \mathrm{M}$ citrate buffer solution ( $\mathrm{pH}$ 6.0) for antigen retrieval and left to stand at room temperature for a further $30 \mathrm{~min}$. After being washed in PBS $(2 \times 5 \mathrm{~min})$, the sections were incubated with blocking solution $(1 \%(\mathrm{v} / \mathrm{v})$ horse serum and $20 \%(\mathrm{v} / \mathrm{v})$ avidin solution (Vector Laboratories) in PBS) for $30 \mathrm{~min}$ to suppress non-specific binding. The sections were then incubated in a humidified chamber with primary antibodies or control antibody overnight at $4{ }^{\circ} \mathrm{C}$. The primary antibodies used were mouse mAbs against human S100A8 (BMA Biomedicals, Augst, Switzerland) and S100A9 (BMA Biomedicals). Both mAbs against S100A8 and S100A9 are specific for the target protein and cross-reactivity between S100A8 and S100A9 was minimal (according to the manufacturer) as measured in a direct ELISA with recombinant human proteins. Considerable cross-reactivity was observed for the human-derived antibodies on bovine tissue (manufacturer's datasheet). Each antibody was thus specific for the target S100 protein. These primary antibodies were diluted at a concentration of $0.2 \mu \mathrm{g} / \mathrm{ml}$ in PBS and $20 \%$ (v/v) biotin solution (Avidin/Biotin blocking kit; Vector Laboratories). The negative control sections were treated in the same manner with $0.2 \mu \mathrm{g} / \mathrm{ml}$ mouse IgG (Vector Laboratories) diluted with PBS and biotin solution. After being washed in PBS $(3 \times 5 \mathrm{~min})$, the sections were incubated with the secondary antibody $(40 \mu \mathrm{g} / \mathrm{ml}$ biotinylated anti-horse IgG in PBS (Vector Laboratories) and $1.6 \%(\mathrm{v} / \mathrm{v})$ horse serum) for $1 \mathrm{~h}$ at room temperature, washed in PBS $(3 \times 5 \mathrm{~min})$, and treated in the avidin-biotin complex solution for $30 \mathrm{~min}$ at room temperature. The sections were then washed in PBS ( $3 \times 5 \mathrm{~min})$ and developed with $3 \%(\mathrm{v} / \mathrm{v}) 3,3-$ diaminobenzidine (ImmPACT DAB Chromogen concentrate) in ImmPACT diluent (ImmPACT DAB Peroxidase substrate; Vector Laboratories) for $1 \mathrm{~min}$ under dark conditions. Positive staining was brown colour and no staining was observed for negative 
controls. The slides were then placed in $\mathrm{dH}_{2} \mathrm{O}$ for 5 min twice before being subjected to perform contrast staining using $10 \%$ (v/v) Gill's Haematoxylin No. 3 in $\mathrm{dH}_{2} \mathrm{O}$ (Park Scientific Ltd.) for $30 \mathrm{~s}$ and washed with running tap water for $5 \mathrm{~min}$. The stained sections were dehydrated in a graded series of ethanol and mounted with VectaMount permanent Mounting Medium (Vector Laboratories) before applying the coverslips.

The presence of inflammatory cells was confirmed using immunostaining methods with the following specific mAbs: CD172A mAb DH59B (macrophage and granulocyte marker; VMRD, Inc., Pullman, WA, USA, used at 1:100 dilution); CD14 mAb MCA1568F (macrophage marker, AbD Serotec, Kidlington, UK, used at 1:50); CD2 (mAb CC42, T-cell and NK cell marker, used at 1:5) and CD8 (mAb CC31, cytotoxic T-cell marker, used at 1:10). The CD2 and CD8 antibodies were kind gifts of Prof. D Werling, Royal Veterinary College, London. The procedures were similar to those described earlier. On day 2, slides were washed with PBS ( $2 \times 5 \mathrm{~min})$ and incubated for $1 \mathrm{~h}$ with dilute secondary antibody using an ABC kit (Vectastain Vector Laboratories) according to the manufacturer's instructions.

\section{Quantification of immunohistochemistry}

Five ROIs selected for analysis were as follows: the luminal epithelium, glandular epithelium and stroma of the intercaruncular endometrium and the luminal epithelium and stroma of the caruncular endometrium, both taken from the previously gravid horn. Endometrial sections were photographed using an Olympus BX-60 microscope by one operator unaware of the treatment by use of a random number system. Images from the entire stained sections were captured in full colour at $\times 400$ magnification and saved as high-resolution digital images (TIFFs). A total of ten images per slide were obtained from each cow, where each slide contained two to three sections. The intensity of staining was scored by a user-defined digital quantitative image analysis system (Volocity 5.5; PerkinElmer, Inc., Waltham, MA, USA) and classified on a scale of $0-3$, where 0 , negative staining; 1 , weak staining; 2, moderate staining and 3, strong staining. For statistical analysis, immunostaining of S100A8 and S100A9 was evaluated using a histology score ( $\mathrm{H}$-score). The $\mathrm{H}$-score was calculated from the intensity and area proportion scores using the following equation: $\mathrm{H}$-score $=(1 \times \%$ area of score 1$)+(2 \times \%$ area of score 2$)+(3 \times \%$ area of score 3$)$, giving a possible range of 0-300 (Pierceall et al. 2011). The same scoring method was used separately on the different ROls of either caruncular or intercaruncular endometrium from each animal for both proteins S100A8 and S100A9.

\section{RNA preparation, microarray analysis and real-time qPCR}

Total RNA was extracted from 200 to $300 \mathrm{mg}$ frozen endometrial tissue from each cow using TRI Reagent (Molecular Research Centre, Cincinnati, OH, USA). RNA concentration and purity of each sample was evaluated using a NanoDrop ND-1000 spectrophotometer (NanoDrop Technologies, Inc., Wilmington, DE, USA), where all samples had an acceptable 260:280 ratio of absorbance between 1.8 and 2.1. RNA integrity was confirmed for all samples using automated capillary gel electrophoresis on a Bioanalyzer 2100 with RNA 6000 Nano Labchips according to the manufacturers' instructions (Agilent, Waldbronn, Germany).

Microarray analysis was performed previously using $24 \mathrm{~K}$ AffymetrixGeneChip Bovine Genome Arrays (Wathes et al. 2009). Only the data for S100A2, S100A8, S100A9 and S100A 12 were used in this study. The mRNA concentration of S100A8 was also determined by a real-time qPCR procedure with a single-plex SYBR Green I assay and reported previously (Wathes et al. 2009). RPL19, GAPDH and RNA18S5 (RN18S1) were tested as reference genes. Analysis of relative quantification from the ratios of the mRNA concentrations of the genes of interest to the reference genes was carried out in parallel with the absolute quantification. However, levels of all three reference genes were not significantly different between SNEB and MNEB groups $(P \geq 0.05)$. The absolute value of $m R N A$ ( $f g / \mu g$ reverse-transcribed $R N A$ ) was therefore used in this study.

\section{Statistical analysis}

Statistical analysis of the data was carried out using SPSS, V18.0. A linear mixed effect model was used for analysis of the effect of NEB status and ROls on the level of immunostaining $\mathrm{H}$-scores for S100A8 and S100A9. This model included NEB status (SNEB and MNEB), ROIs (intercaruncular luminal epithelium, glandular epithelium and stroma, and caruncular luminal epithelium and stroma) as the fixed effects and animal as the random effect. Post hoc comparisons were performed using the Bonferroni test. Data were tested for homogeneity of variance using a Levene test and log transformation was performed if necessary.

Differences in $\mathrm{H}$-score, histological measurement and the number of epithelial and stromal leukocytes in the endometrial sections between MNEB and SNEB groups were analysed using an independent samples $t$-test. Levene test was used to account for variance, and if homogeneity was not achieved, an unequal variance $t$-test was used.

Relationships between the protein measured by immunohistochemistry staining, plasma metabolite and hormone parameter, mRNA values from microarray data and real-time quantitative PCR, and the number of leukocytes in the histology samples were determined from values pooled across treatment groups. The spread of data was tested for normality using the Shapiro-Wilk test and log transformations were performed if appropriate before performing Pearson correlations. The false discovery rate was used to adjust the level of significance to account for multiple comparisons (Benjamini \& Hochberg 1995). Results from all analyses are presented as sample mean \pm S.E.M. Statistical significance was considered at a $P$ value of 0.05 .

\section{Declaration of interest}

The authors declare that there is no conflict of interest that could be perceived as prejudicing the impartiality of the research reported. 


\section{Funding}

This project was funded by the Wellcome Trust (grant number 07213/Z/03/Z) and the Irish National Development Plan. $\mathrm{T}$ Swangchan-Uthai was supported by the Royal Thai Government and Q Chen by the Chinese Scholarship Council.

\section{Acknowledgements}

The authors thank Dr J Murphy and R Fitzpatrick, Teagasc, Ireland, for assistance with the animal work; Dr W Chowdhury for contributions to the immunohistochemistry; Mr A Hibbert, Royal Veterinary College, for assistance in the analysis of staining intensity using Volocity software; Prof. D Werling, Royal Veterinary College, London, for the kind gift of the CD2 and CD8 antibodies and Dr P Pfeifer, BMA Biomedicals, Augst, Switzerland, for kindly providing the S100A8 and S100A9 antibodies. RVC Manuscript No. CBS_00511.

\section{References}

Ahmad A, Bayley DL, He S \& Stockley RA 2003 Myeloid related protein8/14 stimulates interleukin-8 production in airway epithelial cells. American Journal of Respiratory Cell and Molecular Biology 29 523-530. (doi:10.1165/rcmb.2002-0286OC)

Ametaj BN, Emmanuel DG, Zebeli Q \& Dunn SM 2009 Feeding high proportions of barley grain in a total mixed ration perturbs diurnal patterns of plasma metabolites in lactating dairy cows. Journal of Dairy Science 92 1084-1091. (doi:10.3168/jds.2008-1465)

Benjamini Y \& Hochberg Y 1995 Controlling the false discovery rate: a practical and powerful approach to multiple testing. Journal of the Royal Statistical Society B $\mathbf{5 7} 289-300$.

Bondurant RH 1999 Inflammation in the bovine female reproductive tract. Journal of Animal Science 77 (Suppl 2) 101-110.

Bonnett BN, Miller RB, Etherington WG, Martin SW \& Johnson WH 1991 Endometrial biopsy in Holstein-Friesian dairy cows. I. Technique, histological criteria and results. Canadian Journal of Veterinary Research 55 155-161.

Bonnett BN, Martin SW \& Meek AH 1993 Associations of clinical findings, bacteriological and histological results of endometrial biopsy with reproductive performance of postpartum dairy cows. Preventive Veterinary Medicine 15 205-220. (doi:10167-5877(93)90114-9)

Butler WR 2003 Energy balance relationships with follicular development, ovulation and fertility in postpartum dairy cows. Livestock Production Science 83 211-218. (doi:10.1016/S0301-6226(03)00112-X)

Champaiboon C, Sappington KJ, Guenther BD, Ross KF \& Herzberg MC 2009 Calprotectin S100A9 calcium-binding loops I and II are essential for keratinocyte resistance to bacterial invasion. Journal of Biological Chemistry 284 7078-7090. (doi:10.1074/jbc.M806605200)

Chapwanya A, Meade KG, Doherty ML, Callanan JJ, Mee JF \& O'Farrelly C 2009 Histopathological and molecular evaluation of Holstein-Friesian cows postpartum: toward an improved understanding of uterine innate immunity. Theriogenology 71 1396-1407. (doi:10.1016/j.theriogenology.2009.01.006)

Chapwanya A, Meade KG, Foley C, Narciandi F, Evans ACO, Doherty ML, Callanan JJ \& O'Farrelly C 2012 The postpartum endometrial inflammatory response: a normal physiological event with potential implications for bovine fertility. Reproduction, Fertility, and Development 24 1028-1039. (doi:10.1071/RD11153)

Chotimanukul S \& Sirivaidyapong S 2011 Differential expression of toll-like receptor 4 (TLR4) in healthy and infected canine endometrium. Theriogenology 76 1152-1161. (doi:10.1016/j.theriogenology.2011.05. 024)

Cobb SP \& Watson ED 1995 Immunohistochemical study of immune cells in the bovine endometrium at different stages of the oestrous cycle. Research in Veterinary Science 59 238-241. (doi:10.1016/00345288(95)90010-1)
Dale I, Brandtzaeg P, Fagerhol MK \& Scott H 1985 Distribution of a new myelomonocytic antigen (L1) in human peripheral blood leukocytes. Immunofluorescence and immunoperoxidase staining features in comparison with lysozyme and lactoferrin. American Journal of Clinical Pathology 84 24-34.

Davies D, Meade KG, Herath S, Eckersall PD, Gonzalez D, White JO, Conlan RS, O'Farrelly C \& Sheldon IM 2008 Toll-like receptor and antimicrobial peptide expression in the bovine endometrium. Reproductive Biology and Endocrinology 6 53. (doi:10.1186/1477-7827-6-53)

Dobson H \& Smith RF 1998 Stress and subfertility. Reproduction in Domestic Animals 33 107-111. (doi:10.1111/j.1439-0531.1998. tb01326.x)

Drackley JK 1999 Biology of dairy cows during the transition period: the final frontier? Journal of Dairy Science 82 2259-2273. (doi:10.3168/jds. S0022-0302(99)75474-3)

Ehrchen JM, Sunderkotter C, Foell D, Vogl T \& Roth J 2009 The endogenous toll-like receptor 4 agonist S100A8/S100A9 (calprotectin) as innate amplifier of infection, autoimmunity, and cancer. Journal of Leukocyte Biology 86 557-566. (doi:10.1189/jlb.1008647)

Fenwick MA, Fitzpatrick R, Kenny DA, Diskin MG, Patton J, Murphy JJ \& Wathes DC 2008 Interrelationships between negative energy balance (NEB) and IGF regulation in liver of lactating dairy cows. Domestic Animal Endocrinology 34 31-44. (doi:10.1016/j.domaniend.2006.10. 002)

Fischer C, Drillich M, Odau S, Heuwieser W, Einspanier R \& Gabler C 2010 Selected pro-inflammatory factor transcripts in bovine endometrial epithelial cells are regulated during the oestrous cycle and elevated in case of subclinical or clinical endometritis. Reproduction, Fertility, and Development 22 818-829. (doi:10.1071/RD09120)

Foldi J, Kulcsar M, Pecsi A, Huyghe B, de Sa C, Lohuis JA, Cox P \& Huszenicza G 2006 Bacterial complications of postpartum uterine involution in cattle. Animal Reproduction Science 96 265-281. (doi:10.1016/j.anireprosci.2006.08.006)

Galvao KN, Santos NR, Galvao JS \& Gilbert RO 2011 Association between endometritis and endometrial cytokine expression in postpartum Holstein cows. Theriogenology 76 290-299. (doi:10.1016/j.theriogenology.2011.02.REF19=10.1071/RD09120)

Gier HT \& Marion GB 1968 Uterus of the cow after parturition: involutional changes. American Journal of Veterinary Research 29 83-96.

Gilbert RO, Shin ST, Guard CL, Erb HN \& Frajblat M 2005 Prevalence of endometritis and its effects on reproductive performance of dairy cows. Theriogenology 64 1879-1888. (doi:10.1016/j.theriogenology. 2005.04.022)

Griffin JF, Hartigan PJ \& Nunn WR 1974 Non-specific uterine infection and bovine fertility. I. Infection patterns and endometritis during the first seven weeks post-partum. Theriogenology 1 91-106.

Hammon DS, Evjen IM, Dhiman TR, Goff JP \& Walters JL 2006 Neutrophil function and energy status in Holstein cows with uterine health disorders. Veterinary Immunology and Immunopathology 113 21-29. (doi:10.1016/j.vetimm.2006.03.022)

Hartigan PJ, Murphy JA, Nunn WR \& Griffin JF 1972 An investigation into causes of reproductive failure in dairy cows. II - Uterine infection and endometrial histopathology in clinically normal repeat-breeder cows. Irish Veterinary Journal 26 245-247.

Havelock JC, Keller P, Muleba N, Mayhew BA, Casey BM, Rainey WE \& Word RA 2005 Human myometrial gene expression before and during parturition. Biology of Reproduction 72 707-719. (doi:10.1095/biolreprod.104.032979)

Herath S, Fischer DP, Werling D, Williams EJ, Lilly ST, Dobson H, Bryant CE \& Sheldon IM 2006 Expression and function of toll-like receptor 4 in the endometrial cells of the uterus. Endocrinology 147 562-570. (doi:10.1210/en.2005-1113)

Herath S, Lilly ST, Fischer DP, Williams EJ, Dobson H, Bryant CE \& Sheldon IM 2009a Bacterial lipopolysaccharide induces an endocrine switch from prostaglandin $F_{2 \alpha}$ to prostaglandin $E_{2}$ in bovine endometrium. Endocrinology 150 1912-1920. (doi:10.1210/en.2008-1379)

Herath S, Lilly ST, Santos NR, Gilbert RO, Goetze L, Bryant CE, White JO, Cronin J \& Sheldon IM 2009b Expression of genes associated with immunity in the endometrium of cattle with disparate postpartum uterine disease and fertility. Reproductive Biology and Endocrinology 755. (doi:10.1186/1477-7827-7-55) 
Khan KN, Kitajima M, Hiraki K, Fujishita A, Sekine I, Ishimaru T \& Masuzaki H 2009 Toll-like receptors in innate immunity: role of bacterial endotoxin and toll-like receptor 4 in endometrium and endometriosis. Gynecologic and Obstetric Investigation 68 40-52. (doi:10.1159/ 000212061)

Kligman D \& Hilt DC 1988 The S100 protein family. Trends in Biochemical Sciences 13 437-443. (doi:10.1016/0968-0004(88)90218-6)

Kostakis ID, Cholidou KG, Kallianidis K, Perrea D \& Antsaklis A 2010 The role of calprotectin in obstetrics and gynecology. European Journal of Obstetrics, Gynecology and Reproductive Biology 151 3-9. (doi:10.1016/j.ejogrb.2010.03.006)

LeBlanc SJ, Duffield TF, Leslie KE, Bateman KG, Keefe GP, Walton JS \& Johnson WH 2002 Defining and diagnosing postpartum clinical endometritis and its impact on reproductive performance in dairy cows. Journal of Dairy Science 85 2223-2236. (doi:10.3168/jds.S00220302(02)74302-6)

Leung ST, Derecka K, Mann GE, Flint AP \& Wathes DC 2000 Uterine lymphocyte distribution and interleukin expression during early pregnancy in cows. Journal of Reproduction and Fertility 119 25-33. (doi:10.1530/reprod/119.1.25) (doi:10.1530/reprod/119.1.25)

Loor JJ, Dann HM, Everts RE, Oliveira R, Green CA, Guretzky NA, Rodriguez-Zas SL, Lewin HA \& Drackley JK 2005 Temporal gene expression profiling of liver from periparturient dairy cows reveals complex adaptive mechanisms in hepatic function. Physiological Genomics 23 217-226. (doi:10.1152/physiolgenomics.00132.2005)

Matsumoto T, Murao S, Kito K, Kihana T, Matsuura S \& Ueda N 1997 Modulation of S-100 genes response to growth conditions in human epithelial tumor cells. Pathology International 47 339-346. (doi:10.1111/j.1440-1827.1997.tb04506.x)

Naz S, Ranganathan P, Bodapati P, Shastry AH, Mishra LN \& Kondaiah P 2012 Regulation of S100A2 expression by TGF- $\beta$-induced MEK/ERK signalling and its role in cell migration/invasion. Biochemical Journal 447 81-91. (doi:10.1042/BJ20120014)

Nisapakultorn K, Ross KF \& Herzberg MC 2001 Calprotectin expression inhibits bacterial binding to mucosal epithelial cells. Infection and Immunity 69 3692-3696. (doi:10.1128/IAl.69.6.3692-3696.2001)

Ohtsuka H, Koiwa M, Hatsugaya A, Kudo K, Hoshi F, Itoh N, Yokota H, Okada H \& Kawamura S 2001 Relationship between serum TNF activity and insulin resistance in dairy cows affected with naturally occurring fatty liver. Journal of Veterinary Medical Science 63 1021-1025. (doi:10.1292/jvms.63.1021) (doi:10.1292/jvms.63.1021)

Passey RJ, Williams E, Lichanska AM, Wells C, Hu S, Geczy CL, Little MH \& Hume DA 1999 A null mutation in the inflammation-associated S100 protein S100A8 causes early resorption of the mouse embryo. Journal of Immunology 163 2209-2216.

Pierceall WE, Wolfe M, Suschak J, Chang H, Chen Y, Sprott KM, Kutok JL, Quan S, Weaver DT \& Ward BE 2011 Strategies for H-score normalization of preanalytical technical variables with potential utility to immunohistochemical-based biomarker quantitation in therapeutic response diagnostics. Analytical Cellular Pathology 34 159-168. (doi:10.3233/ACP-2011-014)

Rahimi F, Hsu K, Endoh Y \& Geczy CL 2005 FGF-2, IL-1 $\beta$ and TGF- $\beta$ regulate fibroblast expression of S100A8. FEBS Journal 272 2811-2827. (doi:10.1111/j.1742-4658.2005.04703.x)

Roche JF, Mackey D \& Diskin MD 2000 Reproductive management of postpartum cows. Animal Reproduction Science 60-61 703-712. (doi:10.1016/S0378-4320(00)00107-X)

Santos NR, Lamb GC, Brown DR \& Gilbert RO 2009 Postpartum endometrial cytology in beef cows. Theriogenology 71 739-745. (doi:10.1016/j.theriogenology.2008.09.043)

Sheldon IM 2004 The postpartum uterus. Veterinary Clinics of North American Food Animal Practice 20 569-591. (doi:10.1016/j.cvfa.2004.06.008)

Sheldon IM \& Bromfield JJ 2011 Innate immunity in the human endometrium and ovary. American Journal of Reproductive Immunology 66 (Suppl 1) 63-71. (doi:10.1111/j.1600-0897.2011.01034.x)

Sheldon IM \& Roberts MH 2010 Toll-like receptor 4 mediates the response of epithelial and stromal cells to lipopolysaccharide in the endometrium. PLOS ONE 5 e12906. (doi:10.1371/journal.pone.0012906)

Sohnle PG, Hunter MJ, Hahn B \& Chazin WJ 2000 Zinc-reversible antimicrobial activity of recombinant calprotectin (migration inhibitory factor-related proteins 8 and 14). Journal of Infectious Disease 182 1272-1275. (doi:10.1086/315810)
Steinbakk M, Naess-Andresen CF, Lingaas E, Dale I, Brandtzaeg P \& Fagerhol MK 1990 Antimicrobial actions of calcium binding leucocyte L1 protein, calprotectin. Lancet 336 763-765. (doi:10.1016/01406736(90)93237-J)

Swangchan-Uthai T, Lavender CR, Cheng Z, Fouladi-Nashta AA \& Wathes DC 2012 Time course of defense mechanisms in bovine endometrium in response to lipopolysaccharide. Biology of Reproduction 87 1-13. (doi:10.1095/biolreprod.112.102376)

Taylor VJ, Beever DE \& Wathes DC 2003 Physiological adaptations to milk production that affect fertility in high yielding dairy cows. In British Society of Animal Science Occasional Publication, vol 29, pp 37-71. Nottingham, UK: Nottingham University Press.

Thorey IS, Roth J, Regenbogen J, Halle JP, Bittner M, Vogl T, Kaesler S,

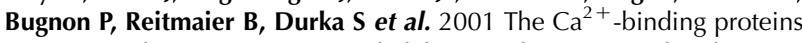
S100A8 and S100A9 are encoded by novel injury-regulated genes. Journal of Biological Chemistry 276 35818-35825. (doi:10.1074/jbc. M104871200)

Turovskaya O, Foell D, Sinha P, Vogl T, Newlin R, Nayak J, Nguyen M, Olsson A, Nawroth PP, Bierhaus A et al. 2008 RAGE, carboxylatedglycans and S100A8/A9 play essential roles in colitis-associated carcinogenesis. Carcinogenesis 29 2035-2043. (doi:10.1093/carcin/bgn188)

Vandal K, Rouleau P, Boivin A, Ryckman C, Talbot M \& Tessier PA 2003 Blockade of S100A8 and S100A9 suppresses neutrophil migration in response to lipopolysaccharide. Journal of Immunology 171 2602-2609.

Veerkamp RF, Koenen EP \& De Jong G 2001 Genetic correlations among body condition score, yield, and fertility in first-parity cows estimated by random regression models. Journal of Dairy Science $\mathbf{8 4} 2327-2335$. (doi:10.3168/jds.S0022-0302(01)74681-4)

Vogl T, Tenbrock K, Ludwig S, Leukert N, Ehrhardt C, van Zoelen MA, Nacken W, Foell D, van der Poll T, Sorg C et al. 2007 Mrp8 and Mrp14 are endogenous activators of toll-like receptor 4, promoting lethal, endotoxin-induced shock. Nature Medicine 13 1042-1049. (doi:10.1038/nm1638)

Wathes DC 2012 Mechanisms linking metabolic status and disease with reproductive outcome in the dairy cow. Reproduction in Domestic Animals 47 (Suppl 4) 304-312. (doi:10.1111/j.1439-0531. 2012.02090.x)

Wathes DC, Fenwick M, Cheng Z, Bourne N, Llewellyn S, Morris DG, Kenny D, Murphy J \& Fitzpatrick R 2007 Influence of negative energy balance on cyclicity and fertility in the high producing dairy cow. Theriogenology 68 (Suppl 1) S232-S241. (doi:10.1016/j.theriogenology. 2007.04.006)

Wathes DC, Fenwick MA, Llewellyn S, Cheng Z, Fitzpatrick RM, SD, Morris DG, Patton J \& Murphy JJ 2008 Influence of energy balance on gene expression in the liver and reproductive tract of lactating cows and consequent effects on fertility. In Factors Affecting Reproduction in the Cow. Eds O Szenci, Cs A Bajcsy. 25th World Buiatrics Congress, Budapest, Hungary, 2008.

Wathes DC, Cheng Z, Chowdhury W, Fenwick MA, Fitzpatrick R, Morris DG, Patton J \& Murphy JJ 2009 Negative energy balance alters global gene expression and immune responses in the uterus of postpartum dairy cows. Physiological Genomics 39 1-13. (doi:10.1152/physiolgenomics.00064.2009)

Wathes DC, Cheng Z, Fenwick MA, Fitzpatrick R \& Patton J 2011 Influence of energy balance on the somatotrophic axis and matrix metalloproteinase expression in the endometrium of the postpartum dairy cow. Reproduction 141 269-281. (doi:10.1530/REP-10-0177)

Werling D \& Jungi TW 2003 Toll-like receptors linking innate and adaptive immune response. Veterinary Immunology and Immunopathology 91 1-12. (doi:10.1016/S0165-2427(02)00228-3)

Yang D \& Oppenheim JJ 2009 Alarmins and antimicrobial immunity. Medical Mycology 47 (Suppl 1) S146-S153. (doi:10.1080/13693 780902721416)

Received 20 December 2012

First decision 31 January 2013

Revised manuscript received 6 March 2013

Accepted 20 March 2013 